\title{
FAR, BUT NOT FAR ENOUGH: AN IDEALIST CRITIQUE OF THE RACIAL EQUALITY DIRECTIVE
}

\begin{abstract}
Tena Šimonović Einwalter*
Summary: Racial discrimination in theory, but also in the reality of today's Europe, is a multifaceted problem. There are no clear boundaries between the personal and social attributes of 'race', ethnicity, religion, culture, nationality or national origin. Is the Racial Equality Directive, as the key legislative tool for combating racial or ethnic discrimination in EC law, wide enough or does it go far enough to successfully address different aspects of contemporary racism? The Directive prohibits discrimination on the ground of 'racial or ethnic origin', but no definition is given of the meaning of 'racial or ethnic origin', while nationality as a ground of discrimination is expressly excluded from its scope, and religion is covered by a different directive. Additionally, the concept of equality underlying the Directive is situated between equality of treatment and a more substantive view of equality, with its remedial model mostly based on the individual justice model' and with the limits of positive action to be allowed under the Directive still unknown. Throughout the paper, an attempt is made to put forward some proposals to revise and update the Directive and to propose some guidelines to interpret the current text in order to set the common minimum at least slightly higher.
\end{abstract}

'Those of us who subscribe to the vision of a pluralistic culture of human rights have the obligation to show how it could be realized.'

Bob Hepple ${ }^{1}$

\section{Introduction}

For a long time, EC law addressed discrimination only on the grounds of sex and Member State nationality. In 1997, with the Treaty of Amsterdam, the Council was given power to take appropriate action to combat discrimination on the ground of sex, as well as on five new grounds: racial or ethnic origin, religion or belief, disability, age, and sexual orientation. In 2000, two directives that address these new grounds were enacted: Council Directive 2000/43/EC of 29 June 2000 implementing the principle of equal treatment between persons irrespective of racial or

\footnotetext{
" Tena Šimonović Einwalter, MJur (Oxon), Legal Advisor to the Croatian Ombudsman.

1 B Hepple, 'Race and Law in Fortress Europe' (2004) 67 (1) MLR 1-15, 2.
} 
ethnic origin, ${ }^{2}$ and Council Directive 2000/78/EC of 27 November 2000 establishing a general framework for equal treatment in employment and occupation. ${ }^{3}$

Regrettably, not all the new grounds have been treated equally. Directive 2000/43/EC on race and ethnic origin has a much wider material scope than Directive 2000/78/EC on religion or belief, disability, age and sexual orientation. ${ }^{4}$ The discrepancy in the material scope of the two directives creates a hierarchy of grounds within EC law, thereby sending a message that some grounds are more important than others. This lack of a coherent approach to equality for all the six discrimination grounds is currently considered one of the principal insufficiencies of EC Antidiscrimination law. ${ }^{5}$

While strongly endorsing a coherent approach to equality across all the grounds, this article posits the view that at the same time all the grounds are different, to the extent that specific issues surround each of the grounds. To use the slogan of the Council of Europe youth campaign against racism, discrimination grounds are, or should be, 'all different, all equal'. ${ }^{6}$ With this in mind and without being able to give a critique of the whole EC equality framework in a single article, this paper will look specifically at the ground of racial or ethnic origin, focusing on the Racial Equality Directive as the key legislative tool for combating racial and ethnic discrimination in EC law.

Even though racial or ethnic origin currently sits at the top of the hierarchy of new grounds, ${ }^{7}$ and even though both the Directive's wide material scope and some of its provisions make it rather progressive, it will be argued that there is some room for clarification and improvement. Focusing on questions related to racial or ethnic origin as a ground of

2 Hereinafter Directive 2000/43/EC, Racial Equality Directive or Directive.

3 Hereinafter Directive 2000/78/EC.

4 In addition, only the Racial Equality Directive requires the establishment of an equality body, while there is no requirement to establish a body for the promotion of equal treatment of all persons without discrimination on the grounds of religion or belief, disability, age and sexual orientation.

5 The most urgent legislative development needed to ensure a comprehensive approach would be the enactment of a new equal treatment directive that covers religion or belief, disability, age and sexual orientation in all the areas covered by the Racial Equality Directive. See Equinet (European network of equality bodies) Opinion of January 2008, Beyond the Labour Market New Initiatives to Prevent and Combat Discrimination, European Commission proposals for new initiatives designed to prevent and combat discrimination outside the labour market based on gender, religion, disability, age and sexual orientation.

6 Council of Europe, ECRI, All Different All Equal: Education Pack Đ Ideas, Tools and Resources for Intercultural Education (European Youth Centre, 1995).

7 For a detailed account of the hierarchy, including the position of sex/gender in it, see E Holzleither 'Mainstreaming Equality: Dis/Entangling Grounds of Discrimination' (2005) Law and Contemporary Problems 927. 
discrimination, this article will argue that although the Directive goes far, it does not go far enough.

Firstly, the question why it took racial discrimination so long to enter EC law is explored and the possible purposes of the Racial Equality Directive are examined, also briefly sketching the main features of the Directive. The central part of the paper identifies some limitations of the Directive, particularly addressing the unclear meaning of 'racial or ethnic origin' as a ground of discrimination. The relationship with discrimination grounds related to 'race', but not explicitly included in the Directive, is discussed, as well as the relationship with religion, which is covered by the Employment Equality Directive. The paper further examines minority protection in the context of the Racial Equality Directive and the effectiveness of the Directive in dealing with discrimination against Roma. It also examines the exclusion of nationality discrimination from the Directive's scope. After considering the question of limits of positive action under the Directive, some conclusions are made about the view of equality underlying the Directive and the enforcement and remedial structure, questioning the effectiveness of the adopted model. Throughout the paper, an attempt is made to put forward some (idealistic) proposals to revise and update the Directive and (more realistically) to propose some guidelines to interpret the current text.

\section{Belated entry of racial discrimination in EC law, the Directive's purpose and main features}

\subsection{Belated entry of racial discrimination in EC law}

Since the Second World War, racial discrimination has consistently been prohibited in international treaties, ${ }^{8}$ regional instruments on human rights protection and general state practice, thereby becoming contrary to customary international law. ${ }^{9}$ At the EU level, racial discrimination entered EC law only in 1997, or more precisely in 1999, while binding legislation was adopted in the year 2000. However, sex discrimination has been present in EC law since the signing of the Treaty of Rome in 1957 through the right to equal pay. ${ }^{10}$ It really came into focus in the mid $1970 \mathrm{~s}^{11}$ and has since become the subject of a number of directives and

\footnotetext{
8 Most notably in the Charter of the United Nations (1945), the Universal Declaration of Human Rights (1948), the International Covenant on Civil and Political Rights (1966), the International Covenant on Economic, Social and Cultural Rights (1966), and in the International Convention on the Elimination of All Forms of Racial Discrimination (1965).

9 M N Shaw, International Law (5th edn Cambridge University Press, Cambridge 2003) 266.

10 Original Article 119 of the EEC Treaty contained the provision prohibiting unequal pay for women and men.

11 Case 43/75 Defrenne v. Sabena (1976) ECR 455 stating that the right to equal pay was directly effective.
} 
a rich jurisprudence, becoming the backbone of the EU's social policy. ${ }^{12}$ So, why has sex discrimination, but not for instance racial or ethnic discrimination, been in the Community's legislative focus for 25 years? ${ }^{13}$

One part of the answer might be that the fight against racial discrimination was perceived to be a human rights issue, and so better and more efficiently dealt with in the framework of the Council of Europe. However, the European Convention for the Protection of Human Rights and Fundamental Freedoms ${ }^{14}$ and the efforts of the European Court of Human Rights were not particularly effective in the field of racial discrimination. The European Court of Human Rights has been rather conservative in ruling on racial discrimination, ${ }^{15}$ finding the first violation of the principle of prohibition of racial discrimination only in July $2005 .{ }^{16}$ The situation has only recently begun to change with the case law on racial discrimination now rapidly growing, particularly regarding Roma and Travellers. ${ }^{17}$ It seems that there is already cross-fertilisation in this field, with the European Court of Human Rights being influenced by the Racial Equality Directive. ${ }^{18}$ Aside from the growing case law, a grand new development in the anti-discrimination field at the Council of Europe is the adoption of Protocol 12, a free standing equality guarantee. ${ }^{19}$

\footnotetext{
12 C Barnard, EC Employment Law (3rd edn Oxford University Press, Oxford 2006) 298.

13 This post festum examination of why it took race discrimination so long to enter EC law as compared to sex discrimination is undertaken without the intention of playing grounds and groups against each other or claiming sex discrimination entered EC law too early, but on the contrary, that it took racial discrimination too long. In this respect, it is interesting that discrimination law in the US developed in the reverse order, focusing first on race, which the US Supreme Court considered to be a suspect category, classifications based on which should be placed under strict scrutiny (see United States $v$. Carolene Products Co (1938) 304 US 144 and Korematsu v. United States (1944) 323 US 214). Only in the 1970s did the US Supreme Court recognise the existence of a history of prejudice against women, although it did not regard classifications based on gender as suspect and used a less intensive level of scrutiny (which was reformulated in the 1990s).

14 To which all EU Member States are signatories.

15 E Sebok, 'The Hunt for Race Discrimination in the European Court' (2002) EUMAP: EU Monitoring and Advocacy Program Online Journal. The ECHR and the Future of Human Rights in Europe <http://www.eumap.org/journal/features/2002/may02/racediscreucourt> accessed 15 April 2008.

16 Nachova and others $v$ Bulgaria (App nos 43577/98 and 43579/98) ECHR 6 July 2005.

17 For the pre-Nachova case law, see Chapman $v$. the United Kingdom (App no 27238/95) [GC] ECHR 18 January 2001; Beard $v$. the United Kingdom (App no 24882/94) [GC] ECHR 18 January 2001; Coster $v$ the United Kingdom (App no 24876/94) [GC] ECHR 18 January 2001; Jane Smith $v$ the United Kingdom (App no 25154/94) [GC] ECHR 18 January 2001; Lee $v$ the United Kingdom (App no 25289/94) [GC] ECHR 18 January 2001; Connors $v$ the United Kingdom (App no 66746/01) ECHR (1st sect) 27 May 2004.

18 D H and others $v$ the Czech Republic (App no 57325/00) [GC] ECHR 13 November 2007.

19 It entered into force on 1 April 2005, but has so far not been widely ratified (for instance, Croatia has ratified it, but the UK, a pioneer of equality legislation, has not).
} 
Another part of the answer might be that as combating sex discrimination in EC law also had an economic rationale of preventing competitive distortions in the market, and as women made up a larger part of the workforce than potential victims of racial discrimination, a choice was made to concentrate on sex equality. However, there is little logic to this argument, since no choice between prohibiting race or sex discrimination was necessary. The same logic of preventing market distortions applies to the prohibition of racial discrimination; moreover, this argument is now being used with respect to discrimination based on racial or ethnic origin. ${ }^{20}$

Yet another part of the answer might be that combating sex discrimination in EC law also served a political goal, as 'sex equality provided a relatively innocuous and even high-sounding platform, by which the Community could demonstrate its commitment to social progress. ${ }^{21}$ Conversely, prohibiting racial discrimination was more sensitive, or, popularly, there was less political will on the part of the Member States to deal with it at the Community level. The European Parliament ${ }^{22}$ had requested time after time that the Council of Ministers enact legislation prohibiting racial discrimination, accompanied by persistent lobbying by the Starting Line Group ${ }^{23}$ over many years, but the Council was very reluctant, ${ }^{24}$ reserving action only to soft law measures. In this reluctance to deal with racial discrimination at Community level probably lies an important part of the answer to the question of the late entry of the prohibition of racial discrimination in EC law.

As to why power was finally given to the Community to combat discrimination based on grounds of racial or ethnic origin and why the Racial Equality Directive was adopted in 2000, literature ${ }^{25}$ most often turns

\footnotetext{
20 See recital 8 in the Preamble of the Directive citing the Employment Guidelines 2000 and recital 9 and the Opinion of Advocate General Poiares Maduro in Case C-54/07 Centrum voor Gelijkheid van Kansen en voor Racismebestrijding $v$ Firma Feryn NV, pending, points 14 and 18.

21 Barnard (n 12) 298; also see Ellis, EU Anti-discrimination Law (OUP, Oxford, 2005).

22 The European Parliament had been active in the fight against racism since the mid-80s, commissioning the Evrigenis report on the rise of racism and fascism in 1984.

${ }^{23}$ See J Niessen and I Chopin, 'The Starting Line and the Racial Equality Directive' in J Niessen and I Chopin (eds), The Development of Legal Instruments to Combat Racism in a Diverse Europe (Martinus Nijhoff Publishers, Leiden 2004).

24 European Parliament, European Union Anti-Discrimination Policy: From Equal Opportunities Between Women and Men to Combating Racism, Directorate-General for Research Working document, LIBE $102 \mathrm{EN}<\mathrm{http}$ ///www.europarl.europa.eu/workingpapers/ libe/102/text1_en.htm>.

25 J Niessen and I Chopin, 'Introduction' in J Niessen and I Chopin (eds), The Development of Legal Instruments to Combat Racism in a Diverse Europe (Martinus Nijhoff Publishers, Leiden 2004). See also M Bell, Anti-Discrimination Law and the European Union (OUP, Oxford Studies in European Law 2002).
} 
to the surge of racism, including racial and ethnic discrimination, which had flooded Europe in the 1990s. Although racial discrimination existed in Europe before the 1990s, racial and ethnic discrimination 'resurfaced at a time when European societies were becoming increasingly diverse as a result of continuous intra and extra European migration. ${ }^{26}$

This rise in racial discrimination and racially motivated violence showed certain commonalities across the Member States, demonstrating the need for a European answer. The then 32 member states of the Council of Europe had at the Vienna Summit in 1993 adopted the Vienna Declaration, a declaration and plan for action on combating racism, xenophobia, anti-Semitism and intolerance, and created the European Commission against Racism and Intolerance (ECRI). The European Council did not have the power to act, so in 1993 in Copenhagen it could only call for the eradication of racism, while in 1994 at the European Council Summit in Corfu the EU Consultative Commission on Racism and Xenophobia was created.

The real Community answer became possible after the Heads of State and Government agreed to change the EC Treaty in June 1997 in Amsterdam by adopting Article $13 \mathrm{EC}$, an empowering provision that enables the Community to take action. ${ }^{27}$ Soon after the entry into force of the Treaty of Amsterdam in 1999, a three-part strategy for the fight against discrimination was adopted. ${ }^{28}$ The Community answer to the growing rise in racial discrimination was the Racial Equality Directive, ensuring a common high level of protection from discrimination, which could not be sufficiently achieved by the Member States acting on their own. ${ }^{29}$

\subsection{The Directive's purpose}

From this account, some conclusions on the purpose of the Racial Equality Directive or the purpose of its adoption can be construed. The purpose of anti-discrimination legislation in general is to give protection and redress to individuals who have been discriminated against, to re-

\footnotetext{
26 Niessen and Chopin (n 25).

27 Article 13 of the EC Treaty states: 'Without prejudice to the other provisions of this Treaty and within the limits of the powers conferred by it upon the Community, the Council, acting unanimously on a proposal from the Commission and after consulting the European Parliament, may take appropriate action to combat discrimination based on sex, racial or ethnic origin, religion or belief, disability, age or sexual orientation.'

28 The strategy to combat discrimination included Directive 2000/43/EC, Directive 2000/78/EC and, through Decision 2000/750/EC, the Community Action Programme 2001-2006 to combat discrimination on all Article 13 grounds except sex (the area of antidiscrimination is now covered by the PROGRESS Programme 2007-2013).

29 Recital 28 of preamble of the Racial Equality Directive, satisfying the subsidiarity principle as set out in Article 5 of the EC Treaty.
} 
duce prejudice by discouraging discriminatory behaviour, to reinforce other measures, and to support people involved in the struggle against discrimination. ${ }^{30}$

Aside from these more general purposes, the Racial Equality Directive had some additional roles and is founded on and legitimated by a number of values. Firstly, referring back to what has been said about the perception of racial discrimination as a human rights issue, one purpose of adopting the Directive was to show that within the Union fundamental human rights now play an important role. ${ }^{31}$ This is exemplified by recital 2 of the Preamble of the Directive, which invokes Article 6 TEU, by which the Union is founded, among other things, on the principle of respect for human rights and fundamental freedoms, but also recital 3 of the Preamble, which invokes key instruments of international law related to discrimination. ${ }^{32}$ Secondly, referring back to the economic rationale, it is recognised in recital 9 of the Preamble that discrimination based on racial and ethnic origin may undermine the attainment of a high level of employment, also invoking the Employment Guidelines 2000 in recital 8 of the Preamble. Thus, there seems to be a convergence of labour market justifications and human rights justifications for the prohibition of discrimination. ${ }^{33}$

Finally and most importantly, referring back to the political dimension, the adoption of the Directive sent a number of significant political messages. As stressed by many authors, ${ }^{34}$ one of the reasons behind the swift adoption of the Directive was the situation in Austria, where in 2000 Jorg Haider's rightwing party entered the coalition government. In that state of affairs, the other Member States did not want to be seen as opposing the adoption of the new Directive combating racial discrimination, sending a strong political message by its quick adoption, both internally and externally. Another foreign policy element was achieved by adopting the Directive prior to the World Conference against Racism, Racial Discrimination, Xenophobia and Related Intolerance held in Johannesburg in $2001 .^{35}$ Finally, a message was sent in the context of enlargement to

\footnotetext{
30 E Howard, 'The EU Race Directive: Its Symbolic Value - Its Only Value?' (2004) 6 International Journal of Discrimination and the Law 143.

31 On this topic, see P Alston, The EU and Human Rights (OUP, Oxford 1999).

32 This has led McInerney to conclude '...one of the first measures to be based explicitly on humanistic values, it heralded a promising new era for the protection of fundamental human rights under E.U. law.' S McInerney, 'Legal Protection Against Discrimination Based on Racial and Ethnic Origin Under European Union Law - Necessary But Not Sufficient?' (2004) 6 International Journal of Discrimination and the Law 8

33 S Fredman, Discrimination Law (OUP, Oxford 2002) 25.

34 For instance: Bell (n 25) 180; E Howard (n 30) 148.

35 S McInerney (n 32).
} 
the future Member States on the Europe's East, who had to transpose the Directives before acceding to the Union.

\subsection{Main features of the Racial Equality Directive}

The 19 article-long Directive 2000/43/EC has been called 'a milestone in the fight against racism in Europe, ${ }^{36}$ 'a decidedly progressive development' which 'heralded a promising new era'37 and 'a major step forward in the fight against racial discrimination across the EU.'38 It establishes minimum requirements, so Member States may introduce or maintain existing provisions that are more favourable to the principle of equal treatment. Furthermore, its implementation should not constitute grounds for a reduction in the level of protection from discrimination already afforded. ${ }^{39}$

It prohibits four types of discrimination: direct discrimination, indirect discrimination, harassment and the instruction to discriminate, of which it explicitly defines direct and indirect discrimination and harassment. Direct discrimination occurs if one person is treated less favourably than another is, has been or would be treated in a comparable situation, on the grounds of racial or ethnic origin..$^{40}$ Indirect discrimination occurs where an apparently neutral provision, criterion or practice would put persons of a racial or ethnic origin at a particular disadvantage compared with other persons. This is so unless the provision, criterion or practice in question is objectively justified by a legitimate aim and the means of achieving that aim are appropriate and necessary. ${ }^{41}$ Harassment is defined as unwanted conduct related to racial or ethnic origin with the purpose or effect of violating the dignity of a person and of creating an intimidating, hostile, degrading, humiliating or offensive environment. ${ }^{42}$

\footnotetext{
36 European Network against Racism (ENAR), Response of the European Network against Racism (ENAR) 'Council Directive implementing the principle of equal treatment between persons irrespective of racial or ethnic origin, 2000/43/EC: Five year report on the application of the Directive - Overview of ENAR's initial assessment' (October 2005).

37 S McInerney, 'Legal Protection Against Discrimination Based on Racial and Ethnic Origin Under European Union Law Đ Necessary But Not Sufficient?' (2004) 6 International Journal of Discrimination and the Law 8.

38 Communication to the Council and the European Parliament on the application of Directive 2000/43/EC of 29 June 2000 implementing the principle of equal treatment between persons irrespective of racial or ethnic origin, Brussels, 30 October $2006 \operatorname{COM}(2006) 643$ final.

39 Art 6 of Directive 2000/43/EC.

40 Art 2.2 (a) of Directive 2000/43/EC.

41 Art 2.2 (b) of Directive 2000/43/EC.

42 Art 2.3 of Directive 2000/43/EC.
} 
The Racial Equality Directive applies to all persons, in both the private and the public sector, in relation to the labour market, including access to employment, access to training, employment and working conditions as well as membership and involvement in organisations of workers and employers. Unlike the Employment Equality Directive, its material scope goes beyond the labour market to cover social protection including social security and healthcare, social advantages, education and access to goods and services, including housing. ${ }^{43}$ It provides for certain exceptions: genuine occupational requirements and positive action. ${ }^{44} \mathrm{~A}$ difference in treatment will not constitute discrimination in cases where this difference in treatment constitutes a genuine occupational requirement. ${ }^{45}$ The Directive neither requires positive action to be maintained or adopted, nor prevents such measures from being maintained or adopted in order to prevent or compensate for disadvantages linked to racial or ethnic origin. ${ }^{46}$

The envisaged route of redress is through the right to make a complaint through a judicial or administrative procedure, including conciliation procedures. ${ }^{47}$ The burden of proof is partially reversed, as once an alleged victim establishes facts from which it may be presumed that there has been discrimination, it is for the respondent to prove that discrimination has not occurred. ${ }^{48}$ Sanctions for those who have discriminated have to be effective, proportionate and dissuasive.$^{49}$ The Directives also prohibits victimisation, so Member States must put in place measures necessary to protect individuals from any adverse treatment as a reaction to a complaint or involvement in the proceedings. ${ }^{50}$ The Directive calls for dissemination of information on its provisions, ${ }^{51}$ for social dialogue, ${ }^{52}$ and dialogue with non-governmental organisations ${ }^{53}$ to foster and promote equal treatment. Finally, it requires the establishment in each Member State of an equality body for the promotion of equal treatment, which should also provide independent assistance to victims of racial discrimination. ${ }^{54}$

\footnotetext{
43 Art 3 of Directive 2000/43/EC.

44 Although whether the provision on positive action constitutes an exception or a way of achieving the goal will depend on the view of equality used.

45 Art 4 of Directive 2000/43/EC.

46 Art 5 of Directive 2000/43/EC.

47 Art 7 of Directive 2000/43/EC.

48 Art 8 of Directive $2000 / 43 /$ EC.

49 Art 15 of Directive 2000/43/EC.

50 Art 9 of Directive 2000/43/EC.

51 Art 10 of Directive 2000/43/EC.

52 Art 11 of Directive 2000/43/EC.

53 Art 12 of Directive 2000/43/EC.

54 Art 13 of Directive 2000/43/EC.
} 


\section{Analysis of the Racial Equality Directive's limitations}

This account of the entry of racial discrimination into EC law shows how unlikely it is that the Directive will be amended in the near future. Firstly, the pressure created by the situation in Austria is no longer present - the internal and external massage has been sent. Secondly, the new security agenda after September $11^{\text {th }}$ created a different set of priorities, requiring some different messages to be sent both internally throughout the EU, as well as externally. Thirdly, since religion, disability, age and sexual orientation are in a much worse position than racial or ethnic origin regarding their status in EC law, amending the Employment Equality Directive seems to be a priority for most actors in the equality field, while the Racial Equality Directive sets the standard to which protection should be extended.

Unsurprisingly, in 2006 the Commission issued a Communication on the application of the Directive, ${ }^{55}$ drawing attention to a number of issues relating to the transposition in Member States, stressing that additional efforts are needed to ensure effective implementation and enforcement at the national level. Although Article 17 of the Directive states that the report on the implementation of the Directive shall, if necessary, include proposals to revise and update the Directive, the Commission stated that it currently does not see a need to come forward with such proposals. There are, however, some limitations and ambiguities in the Directive that should be addressed, as should the current equality framework.

\subsection{The meaning and scope of 'racial or ethnic origin'}

The first issue that arose in this context was whether the word 'race' should be used at all in Community legislation. During the negotiations on the Directive, ${ }^{56}$ some Member States argued that not only the word 'race', but also 'racial origin' should not be used, since using these words reinforces theories of the existence of separate human races, which implies the superiority of some over others. On the other hand, some Member States insisted that the words 'race' and 'racial discrimination' should be used, arguing that it was necessary to name the issue of 'racial discrimination' in order to confront it. As a compromise, the ground was formulated as 'racial or ethnic origin', but recital 6 was added to the preamble: 'The European Union rejects theories which attempt to determine the existence of separate human races. The use of the term "racial origin"

\footnotetext{
55 Communication (n 38).

56 For an account of the negotiations, see A Tyson, 'The Negotiation of the European Community Directive on Racial Discrimination' in J Niessen and I Chopin (eds), The Develop ment of Legal Instruments to Combat Racism in a Diverse Europe (Martinus Nijhoff Publishers, Leiden 2004).
} 
in this Directive does not imply an acceptance of such theories.' In line with their earlier position in their anti-discrimination legislation transposing the Racial Equality Directive, some Member States have avoided using the term 'race'. For instance, Finland uses the concept of 'ethnic or national origin' and Sweden uses 'ethnic belonging'. ${ }^{57}$

The second obviously problematic issue is that the exact meaning of 'racial or ethnic origin' is rather unclear. The Racial Equality Directive prohibits racial discrimination by reference only to 'racial or ethnic origin', while there is no definition of the meaning of 'racial or ethnic origin' in the Directive or in the Explanatory Memorandum. What attributes will, for the purposes of the Directive, be considered to be 'racial or ethnic origin'? As Fredman argues, present-day racism is not just about colour, but also about culture. "The characterization of race as a social construct also makes clear that, as a target for racism, "race" encompasses a bundle of personal and social attributes, including religion, culture, nationality and ethnicity. ${ }^{58}$ It is therefore vital that the tools for combating racial discrimination can address different aspects of contemporary racism.

One way the meaning of 'racial or ethnic origin' could have been clarified would have been by listing these attributes in the text of the Directive as separate but overlapping discrimination grounds distinctions based on which fall into the broad notion of racial discrimination. For instance, the EU Charter of Fundamental Rights prohibits discrimination based on race, colour, ethnic or social origin, language, religion or belief and membership of a national minority, among others. ${ }^{59}$ By using this technique, other discrimination grounds recognised by international law, like colour, national origin, membership of a national minority, language, or culture, could have been included as grounds in the text of the Racial Equality Directive to make it clear that the multifaceted concept of racial discrimination was fully covered. However, that would be more difficult to justify as acting within the competence given in Article $13 \mathrm{EC}$, which states that the Council may take appropriate action to combat discrimination based on a limited number of grounds, one of them being racial or ethnic origin. Another possibility was to define the term 'racial or ethnic origin' or to define 'racial or ethnic discrimination' using these concepts or attributes. This is the technique used by the United Nations' International Convention

\footnotetext{
57 M Bell, I Chopin and F Palmer, Developing Anti-Discrimination Law in Europe: The 25 EU Member States Compared (Luxembourg, Office for Official Publications of the European Communities 2007).

58 S Fredman, 'Combating Racism with Human Rights: The Rights to Equality' in S Fredman (ed), Discrimination and Human Rights: The Case of Racism (OUP, Oxford 2001) 11.

59 The EU Charter of Fundamental Rights art 21 (1) of the Charter states: 'Any discrimination based on any ground such as sex, race, colour, ethnic or social origin, genetic features, language, religion or belief, political or any other opinion, membership of a national minority, property, birth, disability, age or sexual orientation shall be prohibited.'
} 
on the Elimination of all forms of Racial Discrimination, ${ }^{60}$ which defines 'racial discrimination' as any distinction, exclusion, restriction or preference based on race, colour, descent, or national or ethnic origin. By using this technique, the Council would be taking appropriate action to combat discrimination based on racial or ethnic origin, so acting within its competence, and there would be less uncertainty as to the scope and meaning of 'racial or ethnic origin' as a discrimination ground.

The advantage of the approach used in the Racial Equality Directive is it gives more flexibility to national legislators and courts. It will, however, be up to the ECJ to crystallise what exactly 'race or ethnic origin' might encompass in the context of EC law. This will be especially relevant for Member States that have chosen to include just the grounds found in EC anti-discrimination directives in their national anti-discrimination legislation. ${ }^{61}$ One obvious suggestion for an interpretation of the meaning of 'racial or ethnic origin' by the ECJ would be to use the grounds listed in the Charter of Fundamental Rights to inform the interpretation of the Directive. In addition, the definition of 'race' found in ICERD could be used. All Members States of the EU have signed and ratified this Convention, which means the Member States already have certain legal obligations in that respect. Furthermore, the European Court of Human Rights has also used Article 1 of the Convention on the Elimination of Racial Discrimination to define 'race', ${ }^{62}$ with all EU Members States also being members of the Council of Europe. While there is no legal obligation for the ECJ to take into account international human rights instruments when interpreting the Directive, it is worth noting that these instruments (one of them being ICERD) are already cited in recital 3 of the Directive's preamble.

\subsection{The relationship between 'racial and ethnic origin' and religion: a hierarchy of grounds}

A particularly difficult question of the meaning of 'racial or ethnic origin' is the specific question of the boundary between ethnic origin and

\footnotetext{
60 "In this Convention, the term "racial discrimination" shall mean any distinction, exclusion, restriction or preference based on race, colour, descent, or national or ethnic origin which has the purpose or effect of nullifying or impairing the recognition, enjoyment or exercise, on an equal footing, of human rights and fundamental freedoms in the political, economic, social, cultural or any other field of public life.' 'Article 1, International Convention on the Elimination of all forms of Racial Discrimination' (1966), Blackstone's International Law Documents (2nd edn Blackstone Press Limited, London 1994) 121-130 (hereinafter ICERD).

${ }_{61}$ For instance, the current draft of the Croatian Anti-discrimination Act, currently in parliamentary procedure, includes 18 discrimination grounds, among which racial or ethnic origin, colour and national origin/descent, in line with obligations stemming from public international law, namely the International Convention on the Elimination of all Forms of Racial Discrimination.

62 Jersild v Denmark (App no 15890/89) [GC] ECHR 24 September 1994.
} 
religion. In social anthropology, an 'ethnic group' is a population of humans whose members identify with each other, usually based on a presumed common genealogy or ancestry, whereas recognition by others as a separate ethnic group also contributes to defining it. ${ }^{63}$ Ethnic groups are commonly seen as sharing cultural, linguistic and/or religious traits. The European Court of Human Rights has also recently held that 'ethnicity has its origin in the idea of societal groups marked by common nationality, tribal affiliation, religious faith, shared language, or cultural and traditional origins and background. ${ }^{64}$

Although anthropology acknowledges the linkage between religion and ethnicity, for purposes of EC law ethnic origin and religion have been separated. Unlike the aforementioned grounds (such as language), religion is expressly included as a ground of EC anti-discrimination law, but in a different directive from that covering racial or ethnic origin. What makes this separation especially problematic is that the Employment Equality Directive which covers discrimination on the basis of religion or belief has a much narrower scope than the Racial Equality Directive. Through this divergence in scope, a sort of hierarchy of grounds has been created. By prohibiting discrimination on the ground of racial or ethnic origin, but not discrimination on the ground of religion in areas like social advantages or access to goods and services, a message is being sent that discrimination on some grounds is less acceptable than on others. ${ }^{65}$

This separation and hierarchy is also undesirable from the perspective of effectively combating racial or ethnic discrimination. According to current EC law, a person who is a Muslim from Pakistan is protected in the EU from discrimination in the provision of services when it comes to their Pakistani ethnic origin, but not when it comes to being Muslim. While there are of course non-Muslims from Pakistan who are being discriminated against, in the case of persons who are Muslim, how easy will it be to distinguish whether they have been discriminated against on grounds of religion or ethnic origin?

The boundary between the concepts of religion and ethnicity becomes significant once legislation prohibits discrimination on one of the grounds in certain areas, while on the other it does not. Since the law assumes a clear separation between the two concepts, groups like Jews, Muslims, Rastafarians or Sikhs, for instance, have to be classified as being either religious groups or ethnic groups. In addition, irrespective of their self-identification as religious groups or ethnic groups, they have to

\footnotetext{
63 A D Smith, The Ethnic Origins of Nations (Blackwell, Oxford 1986).

64 Timishev v Russia, (App no 55762/00 and 55974/00) [GC] ECHR 13 December 2005.

65 Unfortunately, this could be read as a message that in Europe in certain areas and aspects religious discrimination is somehow acceptable.
} 
claim ethnic group status in order to be protected from discrimination. Earlier UK case law on the Race Relations Act, where groups had to argue that they were ethnic groups in order to fall within the ambit of the Act (as religion was excluded), has provided plenty of examples of the difficulties that can be expected. In the UK, Sikhs ${ }^{66}$ and $\mathrm{Jews}^{67}$ were found to be ethnic groups and so protected from discrimination on the ground of ethnic origin, but Rastafarians ${ }^{68}$ and Muslims ${ }^{69}$ were not. Dutch case law has, on the other hand, recognised that in certain circumstances discrimination against Muslims can fall within the scope of racial discrimination. ${ }^{70}$

As Fredman explains, 'ethnicity is intimately bound up with religion. ${ }^{71}$ The solution to avoid drawing boundaries for legal purposes between concepts which are intertwined is for EC law to adopt a coherent approach to equality, using a common legal standard of protection across all the discrimination grounds. The relationship between ethnic origin and religion would not be legally problematic if one of three solutions were adopted: firstly, one directive could include all the grounds, treating them equally, but allowing for specific exceptions when necessary; secondly, by amending the Racial Equality Directive, religion could be added to 'racial or ethnic origin'; and thirdly, a new directive could be enacted or the existing directive 2000/78/EC amended in order to extend its material scope to that of the Racial Equality Directive. ${ }^{72}$

\subsection{The Racial Equality Directive and (national) minorities}

Perhaps an even more complex question is that of the relationship between the concept of minority protection and non-discrimination in the context of the Racial Equality Directive. It has already been discussed that the exact meaning of 'racial or ethnic origin' found in the Directive is unclear, including the extent to which it encompasses national origin. The meaning of the concept of 'minority' is unclear as well, since there is no generally accepted definition of this term. For instance, instruments

66 Mandla v Dowell Lee [1983] 2 AC 548 HL.

67 Seide $v$ Gillettee Industries Ltd [1980] IRLR 427.

68 Dawkins $v$ Department of Environment [1993] IRLR 284 CA.

69 J. H. Walker $v$ Hussain [1996] IRLR 11 EAT.

70 (Dutch) Equal Treatment Commission, Opinion 1998/57.

71 Fredman (n 33) 70.

72 In my opinion, following the amendment to art 2 of the Racial Equality Directive suggested by the European Parliament would not be enough: 'Discrimination on the basis of racial or ethnic origin which is presented as a difference in treatment on the grounds of religion, conviction or nationality is deemed to be discrimination within the meaning of Article 1.' European Parliament Opinion, A-5-0136/2000 and E Howard, 'The EU Race Directive: Time for a Change?' (2007) 8 International Journal of Discrimination and the Law 246. 
of the United Nations tend to use the concept 'ethnic, religious or linguistic' minorities, while the Council of Europe and the OSCE tend to use the concept 'national' minorities. ${ }^{73}$ Moreover, while Article 13 EC enables combating racial or ethnic discrimination, there is no EC competence regarding minority protection. ${ }^{74}$

The conceptual relationship between minority protection and nondiscrimination can be explained through the construction of minority protection on two pillars. The first concerns non-discrimination in combination with the human rights of relevance for minorities, and the second has to do with minority specific standards of protection and promotion related to the right to identity. ${ }^{75}$ Henrard poses the central question as to whether, in addition to the prohibition of discrimination, 'special' minority rights are also needed, which requires an assessment of the extent to which prohibition of discrimination caters for the specific needs of minorities. ${ }^{76}$ In regard to minorities, it seems crucial to use a more substantive notion of equality, and therefore to recognise that differential treatment might be necessary to reach full equality in practice. However, the right to the preservation of minority identity, including language, culture and religion, is clearly out of the reach of current EC law. ${ }^{77}$ Given its focus on identity, as well as a more substantive view of equality for minorities in the EU, there is clearly added value in the Council of Europe's Framework Convention for the Protection of National Minorities ${ }^{78}$.

\footnotetext{
73 For instance, the Framework Convention for the Protection of National Minorities, a legally binding multilateral instrument devoted to the protection of national minorities in general, which makes it clear that this protection is an integral part of the protection of human rights, but an instrument of the Council of Europe.

${ }^{74}$ As part of the process of accession, the Commission pays great attention to the political criteria, part of which is human rights and the protection of minorities. In Croatia, for instance, all the past progress reports paid particular attention to the Serb minority and to the position of the Roma minority. However, after EU accession, the EU protection of minorities no longer lies within EC competence. The EU, however, focuses on minorities in terms of the European Employment Strategy and the Process of Social Inclusion.

${ }^{75}$ K Henrard, Equal Rights versus Special Rights? Minority Protection and Prohibition of Discrimination (Office for Official Publications of the European Communities, Luxembourg 2007) 14. See also F Benoit-Rohmer, The Minority Question in Europe: towards a coherent system of protection. of national minorities (International Institute for Democracy, Strasbourg 1996).

76 Henrard (n 75).

77 Within the EU toolbox, the most significant and promising development in the area is the inclusion of the prohibition of discrimination based on membership of a national minority in the EU Charter of Fundamental Rights. The EU Network of Independent Experts on Fundamental Rights has also stressed that minority interests can be mainstreamed in, for example, broadcasting, the provision of services of general interest or regarding safeguards for suspects in criminal proceedings. See the EU Network of Independent Experts on Fundamental Rights, 'Report on the situation of fundamental rights in the European Union in 2003' 101Đ103.

78 Provided the relevant Member State has ratified the Framework Convention, as about $25 \%$ have not.
} 
Perhaps a different way of asking the same question is to enquire to what extent the current special rights afforded to national minorities in Member States and future Member States are in line with the Racial Equality Directive. Once again, an interpretation by the ECJ will be needed of the limits of acceptable positive action in relation to 'racial or ethnic origin', an issue that will be further discussed.

Regarding the relationship between the concept of minority protection and non-discrimination in the context of the Racial Equality Directive, it is especially interesting to consider that the picture of diversity is different throughout the EU. On one hand, there are the Member States where the population has over the last decades become diverse on account of migration, although to a differing degree. ${ }^{79}$ On the other hand, the picture of diversity is different for the EU10, whose minorities have mostly lived in the same territory for centuries. Therefore, though also an issue for the 'old Member States', discrimination of (national) minorities appears in a somewhat different context in the EU10 and in Romania and Bulgaria, as well as in the current candidate countries like Croatia. ${ }^{80}$ While minority protection is relevant for all the Member States, for some Member States and future Member States that have not been destinations of recent migration, effectively combating racial or ethnic discrimination in practice will mainly mean combating the discrimination of some of these long-standing minorities or national minorities. Here, the statement that contemporary racism is not about colour, but about culture, will have particular significance.

A part of the symbolic value of the Directive was to send a message to the future Member States that they will have to combat racial and ethnic discrimination when they accede to the EU. On the other hand, it is questionable whether issues like the interplay of the concept of national minorities within the national legislation ${ }^{81}$ of those states with the Racial Equality Directive were taken into account when the Racial Equality

\footnotetext{
79 Some Member States, like the UK, France and the Netherlands, have taken in immigrants from their former colonies; some, like Germany, Austria, Sweden, but also to a degree Belgium, Denmark and Luxembourg, have for years taken in 'guest workers', while others have only recently become destinations of immigration. See B Liegl, B Perching and B Weyss, Combating Religious and Ethnic Discrimination in Employment from the EU and International Perspective (2004) ENAR 4.

80 In Croatia, according to the 2001 census, $89.6 \%$ of people have declared themselves as Croatians, $7.5 \%$ as members of one of the 22 recognised national minorities, $2 \%$ did not declare a national origin, while 0.5 declared themselves as "others" (with $0.2 \%$ declaring a 'regional belonging' and $0.4 \%$ unknown). S Tatalović, Nacionalne manjine u Hrvatskoj, (Stina, Split 2005) 23.

81 Croatia, for instance, has detailed and specific laws referred to above on national minorities (the Constitutional Act on the Rights of National Minorities, the Act on the Election of Members of Representative Bodies of Units of Local and Regional Self-government, the Act on the Use of the Languages and Scripts of National Minorities in the Republic of Croatia, and the Act on Education in the Languages and Scripts of National Minorities).
} 
Directive was being drafted. Some statements regarding the issue like it is often unclear whether the concept of ethnic/national minority found within these laws will be relied upon when national courts interpret antidiscrimination legislation' 82 and 'in a few Member States the redefining of members of national minorities may have an impact on equal treatment, but it is too early to assess the impact fully in the context of the Directive', as well as 'the grounds and scope of protection can have key differences and accord a particular status to communities'83 show this relationship remains under explored.

It has been noted that in the Europe's East and Southeast, relationships among different ethnic groups have been heavily influenced by centuries of rival nationalisms within the former Turkish, Russian and Austro-Hungarian empires. ${ }^{84}$ The Southeast especially may pose new questions regarding non-discrimination of national minorities. Concerning Croatia as a candidate country currently in the process of enacting its new anti-discrimination legislation transposing Directives 2000/43/ EC and 2000/78EC, as well as other candidate and potential candidate countries of Southeast Europe, relations between ethnic groups have had a specific tone. Unlike racial and ethnic discrimination in the majority of the EU, which at least in the mainstream of society has taken on more subtle guises in the past decades, ethnicity and membership of a national minority have played an important part in recent wars. Brennan might be right in saying:

The entry of the accession countries into the legislative ambit of EU race discrimination law is likely to present an interesting and different challenge to that which was probably envisaged by the authors of the Race Equality Directive. Issues such as that of culture and language, the rights of national minorities, and the mesh of religion and ethnicity are likely to test the legal imagination. ${ }^{85}$

\subsection{Effectiveness of the Racial Equality Directive in dealing with discrimination against Roma}

When focusing on the implementation of the Racial Equality Directive in the Europe's East and Southeast, another issue that often appears

\footnotetext{
82 Bell, Chopin and Palmer (n 57).

83 European Monitoring Centre on Racism and Xenophobia, Application of Council Directive 2000/43/EC of 29 June 2000 - Views of the European Monitoring Centre on Racism and Xenophobia, Vienna, August $2005<$ http://www.eumc.at/eumc/material/pub/discussion/EUMC Paper art13 impact final.pdf $>$ accessed 14 April 2008.

84 A Dummet, 'Implementing European Anti-Discrimination Law: A Critical Analysis' in Niessen and Chopin (n 23) 237.

85 F Brennan, 'EU Enlargement, the Race Equality Directive and the Internal Market' in European Union Studies Association (EUSA) Biennial Conference 2005 (9th), 31 March-2 April 2005, Austin, Texas <http://aei.pitt.edu/2981/> accessed 5 March 2008.
} 
is that of the specific situation of Roma. ${ }^{86}$ The focus on Roma in the context of enlargement has led to the realisation that Roma have faced and face particularly grave discrimination all over the European Union. This warrants a specific examination of the adequacy of the current protection from racial or ethnic discrimination in EC law as it relates to the Roma community, namely whether the Racial Equality Directive is adequate for addressing discrimination against Roma.

There are several reasons why many recent EU, Council of Europe and other initiatives have focused on the discrimination of Roma and Romani rights. Mainly, looking at various indicators of social inclusion, Roma seem to be the worst off as a group in virtually all of the EU. ${ }^{87}$ There is a significant difference between the socio-economic situation of Roma and non-Roma throughout Europe. The fields where Roma are particularly prone to discrimination are housing, education, employment and healthcare. The situation is additionally aggravated by the fact that Roma often do not have personal documents, which creates a barrier to the enjoyment of most rights. Additionally, Roma have throughout history faced negative stereotypes, which the low level of interaction between Roma and non-Roma only perpetuates. Furthermore, after the recent enlargements, the Roma have become the largest ethnic minority in the European Union.

Regarding the effectiveness of the Racial Equality Directive in combating discrimination of Roma, in the Communication on the application of Directive 2000/43/EC the Commission especially emphasised the success the Directive has had in addressing discrimination faced by Roma: 'In the majority of the EU 10, statistics showed the Roma as the group most represented in complaints. ${ }^{88}$ It has also been noted that the number of cases taken up by Roma indicates that the Directive is being successfully used to challenge discrimination against this group. However, given the extent of discrimination Roma experience all over the EU, the fact that in some Member States more cases are taken up by Roma than other minority groups might not be an indication of success in tackling discrimination faced by Roma, as suggested in the Communication. ${ }^{89}$ According to a statement from April 2008 from the Fundamental Rights Agency, it has

86 While respecting diversity within many different Romani groups and related communities, for reasons of brevity, hereinafter the term 'Roma' will be used to include persons describing themselves as Roma, Gypsies, Travellers, Manouches, Sinti, as well as other terms.

87 See AG Robles, Final Report on the Human Rights Situation of the Roma, Sinti and Travellers in Europe, CommDH (2006)1; also Focus Consultancy Ltd, ERRC and ERIO, The Situation of Roma in an Enlarged European Union (Office for Official Publications of the European Communities, Luxembourg 2004).

88 Communication (n 38) 4.

89 See ENAR (n 36). 
been recognised that: 'We have put in place strong legislation to root out discrimination in the EU, but the promise of equal opportunity remains unfulfilled for many Roma and Travellers in our societies. ${ }^{90}$

With respect to possible amendments of the Racial Equality Directive or other initiatives, a question that seems to come up in particular is whether Roma are in some way different from other ethnic groups with respect to the discrimination they face. If so, this would have implications for changes to the current system in order to combat more efficiently discrimination against Roma. The principal argument for this assertion is that unlike other groups Roma suffer segregation, particularly in the field of education. ${ }^{91}$ Accordingly, there have been a number of proposals for the further development of legal instruments at EU level, which would be focused specifically on Roma and could be based on Article 13 EC. Mainly, the European Union Network of Experts in Fundamental Rights has recommended the adoption of a 'Directive specifically aimed at encouraging the integration of Roma', based on the inappropriateness in several respects of Directive 2000/43/EC, which was not specifically aimed at achieving the integration of groups that have traditionally been excluded. ${ }^{92}$ However, after initial discussions in 2004, the matter now seems to lie dormant.

\subsection{Nationality and the Racial Equality Directive}

It has been noted that 'the distinction between grounds of racial or ethnic origin covered by the Directive and nationality and national origin has led to some confusion. ${ }^{93}$ According to Article 3 of the Directive regarding its scope, 'this Directive shall apply to all persons'. Recital 3 of the Preamble also says that 'protection against discrimination for all persons

\footnotetext{
${ }^{90}$ A Crickley, Chairperson of the Fundamental Rights Agency's Management Board, in a statement ahead of International Roma Day (8 April 2008) <http://fra.europa.eu/fra/index.php> accessed 15 April 2008.

${ }^{91}$ Secondly, a reality specific to Roma as a group is their statelessness, which not only makes them more vulnerable to discrimination, but also has implication for their culture, as unlike other ethnic groups there is no state that has as one of its tasks the preservation of Romani culture.

92 European Union Network of Experts in Fundamental Rights 'Report on the Situation of Fundamental Rights in the European Union for 2003', dated January 2004, published on 26 May 2004; other informal proposals have included a proposal for a 'Desegregation Directive' covering the fields of education, housing and health, as well as the 'Positive Action Directive' which would bind EU Member States to undertaking positive action measures for minorities, which would include a specific chapter on Roma, or otherwise make specific reference to Roma.

93 European Monitoring Centre on Racism and Xenophobia, Application of Council Directive 2000/43/EC of 29 June 2000 - Views of the European Monitoring Centre on Racism and Xenophobia, (Vienna 2005) http://www.eumc.at/eumc/material/pub/discussion/ EUMC Paper art13 impact final.pdf $>$ accessed 8 April 2008.
} 
constitutes a universal right'. However, during negotiations, upon the insistence of some Member States worried about the possible influence on their immigration system, recital 13 and Article 3, paragraph 2 were added. Recital 13 of the Preamble states: 'This prohibition of discrimination should also apply to nationals of third countries', but then goes on to say 'but does not cover differences of treatment based on nationality', also adding 'and is without prejudice to provisions governing the entry and residence of third country nationals and their access to employment and occupation.' Finally, Article 3, paragraph 2 reiterates that the Directive does not cover differences of treatment based on nationality and is without prejudice to provisions governing the entry and residence of third country nationals and their access to employment and occupation, but also to this adds 'stateless persons on the territory of Member States', and 'any treatment which arises from the legal status of the third-country nationals and steles persons concerned.'

Therefore, the Racial Equality Directive applies to all persons living in EU territory, irrespective of their nationality. It has especial relevance for third country nationals, who are frequently victims of discrimination. However, differences of treatment based on nationality as a discrimination ground are expressly excluded from the scope of the Directive. Nationals of EU Member States are nonetheless protected from nationality discrimination through Article 12 EC. What this means, however, is that third country nationals are not protected from nationality discrimination. Much like the situations described earlier regarding the relationship of 'racial or ethnic origin' and other grounds, here too it will be difficult to draw the boundary between discrimination on grounds of racial or ethnic origin and discrimination on grounds of nationality. For instance, a person of Albanian nationality who is discriminated against in Italy on grounds of ethnic origin ('being Albanian') is protected in the same way as Italian nationals, but the Directive does not apply if discrimination is on grounds of being an Albanian national (being Albanian). Since 'victims of racial slurs and violence are usually identified in terms of their nationality rather than racial identity (eg, Moroccan or Turkish workers) ${ }^{\prime 94}$ one has to wonder how this distinction can be upheld.

Hepple makes a strong case in his critique of the Racial Equality Directive of the exclusion of nationality as a ground of discrimination. By first warning of the distinction between immigration policy and the way individual migrants are treated, he ascertains that the "universality of human rights is undermined by being restricted to those who are nation-

\footnotetext{
94 McInerney (n 32) 14 quoting Curtin and Geurts, 'Race Discrimination and the European Union' (1996) 14 Netherlands Quarterly of Human Rights 147-171.
} 
als of the EU states. ${ }^{95}$ Regarding possible amendments, nationality could be included in the scope of the Racial Equality Directive as a specific ground or in the definition of 'racial or ethnic origin' or 'racial or ethnic discrimination', as was earlier discussed for other grounds related to racial discrimination, but not included in the anti-discrimination directives. A particularly useful suggestion seems to be that differential treatment based on nationality could be considered as discrimination, unless it can be objectively justified, in line with the General Recommendation on Discrimination Against Non-citizens, issued by the Committee on the Elimination of All Forms of Racial Discrimination, the treaty body of the Convention on the Elimination of Racial Discrimination. ${ }^{96}$

\subsection{Limits of positive action under the Directive}

A topic touched upon in earlier discussions of 'special' rights of minorities that form part of minority concerns, as well as effectively combating discrimination faced by Roma, is the issue of positive action. Positive action is a controversial topic, further complicated by a variety of terms used in this context ${ }^{97}$ that do not clearly provide any demarcation. Article 5 of the Racial Equality Directive does not provide clear guidance as to what measures will be allowed. Since the ECJ has not yet interpreted what type of measures are allowed, one way to think about the approach the ECJ might adopt in its future case law regarding positive action with regards the Racial Equality Directive is in relation to the existing approach to positive action as a means of countering sex discrimination.

There are three possibilities, although two are more likely than the other. Firstly, it might, based on the difference in text, ${ }^{98}$ interpret the positive action provisions of the Racial Equality Directive more narrowly than in the case of gender. An indication in favour of this interpretation would also be the special provision concerning Northern Ireland in Directive 2000/78. As some authors have expressed it: 'the demarcation line will be drawn when it comes to quota regulations... I doubt that quota regulations would be regarded as legitimate when it comes to the "other"

\footnotetext{
95 Hepple (n 2) 3-4.

96 Howard (n 72) 252.

97 The terms used include 'positive action', 'positive measures', 'preferential treatment', 'reverse discrimination', 'quota system', 'affirmative action' in the US context, and 'employment equity' in the Canadian context.

98 The wording of the positive action provision regarding sex discrimination seems to be to some extent broader and more inclusive. According to the Equal Treatment Directive, Member States are allowed to "maintain or adopt measures within the meaning of art 141(4) of the Treaty with a view to ensuring full equality in practice between men and women.' These measures may provide for 'specific advantages' for the under-represented sex, aimed at making it easier 'to pursue a vocational activity or to prevent or compensate for disadvantages in professional careers.'
} 
grounds. ${ }^{99}$ Secondly, the ECJ might adopt an integrated approach to all the grounds and start creating an integrated body of anti-discrimination case law, based on the standards created in gender-related positive action cases. This would mean that minor differences in positive action provisions would be ignored and that the Marshall formula ${ }^{100}$ would be applied across the board. Preferential treatment could then be implemented in favour of a racial or ethnic minority, under certain conditions. Thirdly, there is the theoretical possibility that the approach to positive action under the Racial Equality Directive would be more geared towards preferential treatment than in the case of EC law on gender equality. This possibility is, however, highly unlikely, given the political sensitivities involved in questions of race or ethnicity.

A different way of thinking about the approach the ECJ might adopt in its future case law regarding positive action is to pose the question about how appropriate a role this is for the ECJ at all. Caruso ${ }^{101}$ argues that transplanting the approach used with gender to the new grounds of discrimination will be difficult. She points out that there needs to be sensitivity to the socio-economic and cultural context at the national level and recommends that the ECJ provides broad discretion for Member States. That would allow the Member States to modify positive action according to the local context. This proposal becomes particularly interesting when considered in light of the debates on the role of the non-binding guidelines at EU level. The Swedish case Abrahamsson and Anderson $v$ Fogelquist ${ }^{102}$ makes one wonder whether it should be the role of EC law and the ECJ to place a low ceiling on the measures and policies of preferential treatment that the national system was able to agree upon. As well as rethinking an approach to positive action regarding gender equality, this is particularly interesting considering that the Racial Equality Directive establishes the minimum standard. This should mean that the Member States are allowed to go further in search of policies aimed at achieving equality. However, this is not so when the ECJ places the limit as to how far. ${ }^{103}$ As a possible amendment of the Directive, positive action

\footnotetext{
99 Holzleithner (n 7).

100 After the heavily criticised Kalanke, in the 1997 Marschall case the ECJ decided that if women have the same qualifications as men they can receive preference for promotion in areas where they are underrepresented if the male candidate could point to alternative criteria of preference (the saving-clause), thereby drawing the line between preferential treatment legitimate in EC law from fixed-quota systems. This formula was confirmed in the Badeck decision. See Kalanke C-450/93 [1995] ECR I-3051; Marschall $v$ Land Nordrhein Westfalen C-409/95 [1997] ECR I-6363; Badeck C-158/97 [2000] ECR I-1875.

101 HCD Caruso, 'Limits of the Classic Method: Positive Action in the European Union After the New Equality Directives' (2003) Harvard International Law Journal 331.

102 Case C-407/98 Abrahamsson and Anderson v Fogelquist [2000] ECR I-5539.

103 As Caruso puts it: 'This construct has the comforting flavour of subsidiarity and the support of considerable acquis in the field of gender equality. The problem with this con-
} 
could be made mandatory, as will be discussed more in relation to the equality model used in the context of enforcement and remedies, but the limits of acceptable positive action nevertheless remain a crucial issue.

\subsection{Underlying view of equality}

Going back to the analysis of its purpose, the Directive proclaims in Article 1 that its purpose is to lay down a framework for combating discrimination on the grounds of racial or ethnic origin, with a view to putting into effect in the Member States the principle of equal treatment, while Article 5 begins with the formulation "with the view to ensuring full equality in practice.' However, before analysing what view of equality underlies the Directive, some theoretical considerations are in order, as equality is not a straightforward term. One theory of conceptualising different notions of equality is the separation of formal equality and substantive equality, which is then subdivided into equality of opportunity and equality of results. ${ }^{104}$ One concept of equality is formal equality or equality of treatment, according to which justice requires consistency and, therefore, likes should be treated alike. It does not take into account the existing distribution of wealth and powers and is primarily concerned with individual rights, not group rights, and the concept of direct discrimination. On the other side of the spectrum is the concept of equality of outcomes or results, which is focused on the existing inequality of the distribution of wealth and power and strives to improve the relative position of particular groups. It is associated with the concept of indirect discrimination and the group rights model.

A particular model of equality adhered to by EC anti-discrimination law is equality of opportunity. It focuses on facilitating personal self-fulfilment by equalising opportunities. Fredman explains it as a race in which some athletes are put a little bit ahead of others, but they all still need to run in order to see who will come first to the finish line. ${ }^{105}$ It stands somewhere in between the two aforementioned concepts of equality and is consistent with both of them. According to equality of opportunity, unequal treatment might be necessary to equalise the opportunities of all individuals, but once opportunities are equal, different choices and capacities might lead to inequality of results. More critically, however, it seems that since the concept of equality of opportunity works like a

struct is that, as usual, the internal consistency of the floor imposes conceptual limits upon the height and shape of the ceiling. The two are so conceptually tied to each other that the States' freedom to experiment with affirmative group policies, graciously given them by EC legislators, is intrinsically curtailed by the ECJ's equality review' Caruso (n 101).

104 Fredman (n 33) and (n 58) 11; S Fredman, ‘Equality: A New Generation? (2001) 30 ILJ 145

105 Fredman (n 33). 
compromise solution between formal and substantive equality, there is sometimes some confusion about what it is really trying to achieve in practice.

Looking at the provisions of the Directive, it appears to be the perfect example of the equality of opportunity model. Its title 'implementing the principle of equal treatment between people irrespective of racial or ethnic origin' and the stated purpose 'with a view to putting into effect in the Member States the principle of equal treatment' show elements of formal equality. On the other hand, its provision on positive action allows specific measures to be maintained or adopted to prevent or compensate for disadvantages linked to racial or ethnic origin 'with a view to ensuring full equality in practice', which points to a more substantive notion of equality. The process-based definition of direct discrimination is rather formalistic, but it includes a hypothetic comparator. The definition of indirect discrimination is more generous, while the definition of harassment links equality to dignity as an underlying value, again moving away from the formal notions of equality. It appears that just like the concept of equality of opportunity itself, the concept of equality underlying the Directive is situated between equality of treatment and a more substantive view of equality approaching equality of results.

\subsection{The equality model used in relation to enforcement and remedies}

McCrudden distinguishes between three models of equality in relation to enforcement and remedies. ${ }^{106}$ First is an 'individual justice model', focused on fairness for the individual, by, for example, granting a civil remedy to a single victim of discrimination which has succeeded in a court case. The second is a 'group justice model', aiming to improve the position of a certain group, through, for example, class action and strategic public interest litigation or through pressure for change through public procurement. The third is the 'participative model', aiming for greater participation of disadvantaged groups through tools like equality mainstreaming and necessarily through the involvement of the groups in question. Analysing the Racial Equality Directive, McCrudden concludes its remedial model is mostly based on the 'individual justice model'.

A more realistic proposal would be to strengthen the existing model, for instance by strengthening the equality bodies. Through an amendment of the Directive, they should be made independent, ${ }^{107}$ as opposed

\footnotetext{
106 See C McCrudden, 'International and European Norms Regarding National Legal Remedies for Racial Inequality' in Fredman (n 58) 11.

107 In accordance with the Paris Principles.
} 
to just having to exercise their functions independently. An element of independence reviewed should also be how the equality body obtains its funding, as independent funding and spending are a great guarantee of independency. Furthermore, the equality bodies have to be well resourced, both in terms of funds and expertly trained personnel in sufficient numbers. In addition, Article 7 of the Directive could be amended so that associations with a legitimate interest have the right to engage on behalf of the complainant, with his or her approval, in any judicial and/ or administrative procedure. ${ }^{108}$

A characteristic of anti-discrimination in general, and also of the Racial Equality Directive and the national legislation transposing it, is that very few cases are settled in court, because of the reluctance of victims for fear of further victimisation, but also the worry of bearing the costs of a long and expensive lawsuit with an uncertain outcome. ${ }^{109} \mathrm{~A}$ change could therefore be made in the model used in order to approach more what McCrudden calls the 'group justice model' and what Fredman calls ' $4^{\text {th }}$ generation equality'. ${ }^{110}$ Hepple, in urging a shift in models towards $4^{\text {th }}$ generation equality notes: 'The Race Directive is based on a British model of the 1970s rather than what is required in the $21^{\text {st }}$ century in Europe in order to achieve racial equality. ${ }^{111}$

This does not mean that granting a civil remedy to a single victim of discrimination which has succeeded in a court case would be abandoned, just that some new elements could be imported in EC law. For instance, positive action could be made mandatory. Additionally, its limits could be made more flexible, in accordance with the needs of the disadvantaged groups, given there is agreement on a particular action in the Member State. The positive duties of public bodies to promote equality could be added to the Racial Equality Directive, requiring a change in the general approach, not just in post festum justice for the parties involved. As Hepple argues 'A positive duty to reduce the under-representation of disadvantaged groups is, in the long run, more effective than negative duties not to discriminate. ${ }^{112}$ The Member States could also introduce systems of contract and subsidy compliance, and so condition contracts with good equality 'track records' of businesses.

\footnotetext{
108 As opposed to the current wording of Article 7 by which associations with a legitimate interest "may engage on behalf or in support of the complainant, depending on the criteria laid down by national law'.

109 Communication (n 38).

110 See Fredman (n 33).

111 Hepple (n 2) 12.

112 Hepple (n 2) 14.
} 


\section{Conclusion}

Thomas Hammarberg, ${ }^{113}$ the Council of Europe Commissioner for Human Rights, includes among key human rights challenges in Europe today racism and xenophobia, the rights of migrants and discrimination against Roma people. The enactment of the Racial Equality Directive at EU level, as well as the subsequent amendment of existing legislation and the adoption of new anti-discrimination laws in Member States, doubtlessly represents a major step forward in tackling discrimination based on racial or ethnic origin. However, this article has argued there are some limitations and ambiguities in the Directive that should be addressed.

The exact meaning of 'racial or ethnic origin' as a discrimination ground will remain unclear until the ECJ clarifies which attributes will be included in the meaning of 'racial or ethnic origin', or elucidates the distinction based on which specific attributes will constitute 'racial or ethnic discrimination' for the purposes of the Directive. It will, however, be vital that a wider definition is adopted, inspired by the Charter of Fundamental Rights and CERD, in order to enable the Directive to successfully address different aspects of contemporary racism.

Racial discrimination in theory, but also in the reality of today's Europe, is a multifaceted problem. 'Race', ethnicity, nationality, national origin, language and religion intertwine. Legislation in this field should therefore attempt to find a way to regulate complex realities without artificially compartmentalising interconnected concepts. A formal and narrow conception of racial discrimination, which denies the interplay of concepts like religion or nationality with racial or ethnic origin, is insufficient as part of an effective tool to combat racial discrimination. For instance, expressly excluding differences of treatment based on nationality from the scope of the Racial Equality Directive and thereby not protecting third country nationals from nationality discrimination is an example of such insufficiency of current EC anti-discrimination law.

The hierarchy of discrimination grounds has been identified as a problematic feature of the current framework, with a signal being sent that among the Article $13 \mathrm{EC}$ grounds some are more important than others. This article has argued that even though racial or ethnic origin currently sits at the top of the hierarchy of new grounds, this hierarchy is also undesirable from the perspective of effectively combating racial or ethnic discrimination. The separation of racial or ethnic origin and religion into two separate directives is artificial, while the divergence in the

113 T Hammarberg, 'No Place for Complacency about Human Rights' (Presentation, Brussels, October, 2007) <https://wcd.coe.int/ViewDoc.jsp?id=1201099\&Site=CommDH\&Ba ckColorInternet=FEC65B\&BackColorIntranet=FEC65B\&BackColorLogged=FFC679> ac cessed 14 April 2008. 
material scope of the directives exacerbates the situation. A particularly unfortunate consequence is that in areas like the provision of goods and services, in order to be protected from discrimination, religious groups might have to claim ethnic group status, while the classification of the group as a religious or ethnic minority becomes a matter of judicial decision-making.

Regarding the relationship between the concept of minority protection and non-discrimination, it has been concluded that using a substantive notion of equality is necessary, but for minority identity rights the Convention for Protection of National Minorities remains essential. It has also been recognised that while minority protection is relevant for all the Member States, for some Member States and future Member States that have not been destinations of recent migration, effectively combating racial or ethnic discrimination in practice will mainly mean combating discrimination against national minorities. It will be important to recognise that belonging to a national minority is a status or attribute clearly covered by the scope of 'racial or ethnic origin'. This will have particular significance for South East European countries, current candidates and potential candidates for EU accession, given their recent history and the role ethnicity, but also national minority status, has played. With respect to Roma, also a national minority in some states, identity preservation (as the 'second pillar') is important, but much still remains to be done regarding the 'first pillar' of non-discrimination, which might require some specific action.

There are limits to what law can do in the fight against discrimination, especially law signifying legal norms whose violation leads to a court decision that creates justice only for those involved. The possibilities are greater if the law mandates awareness raising, social dialogue and dialogue with non-governmental organisations with a view to promoting equality, as the Racial Equality Directive does. Finally, law could also require the mandatory adoption of positive action, and could put an emphasis on the positive duties of different duty bearers. However, the approach the ECJ might adopt in its future case law regarding positive action remains crucially important, also regarding the above-mentioned minority rights, as well as positive action measures for Roma.

One could argue that given the principles of subsidiarity and proportionality it is not reasonable to expect all of the above from Community legislation. The Racial Equality Directive only sets the minimum standard and it is for the Member States to go beyond it if they so wish. However, now that there is EC equality law dealing with six different discrimination grounds, at least from an idealistic perspective it should offer a comprehensive minimum standard that goes beyond the standards of public international law that already oblige the EU Member States. Discrimination 
is a complex problem that operates differently from ground to ground and within a single ground from Member State to Member State, from group to group. Consequently, it requires complex solutions, which should also be different from Member State to Member State, from context to context. However, in the $21^{\text {st }}$ century Europe, the common minimum should be set high. This article has outlined some ambiguous aspects of the Racial Equality Directive and offered some direction on future interpretation, as well as some possible amendments, in an idealistic attempt to show how the European minimum line could be set at least slightly higher. 